\title{
Sports Activities for Undergraduate Students in Saudi Arabia Universities: A Systematic Literature Review
}

\author{
Sameer Mohammed Sayyd ${ }^{1,2, *}$, Zainal Abidin Bin Zainuddin², Diyana Zulaika Binti Abdul Ghan ${ }^{2}$, \\ Zayed M Altowerqi ${ }^{2,3}$
}

\author{
${ }^{1}$ Department of Physical Education, Faculty of Education, Taibah University, Saudi Arabia \\ ${ }^{2}$ Faculty of Social Sciences and Humanities, School of Education, University Technology Malaysia, Malaysia \\ ${ }^{3}$ Department of Physical Education, Faculty of Education, Umm Al-Qura University, Saudi Arabia
}

Received October 29, 2019; Revised December 24, 2019; Accepted December 27, 2019

Copyright $\odot 2020$ by authors, all rights reserved. Authors agree that this article remains permanently open access under the terms of the Creative Commons Attribution License 4.0 International License

\begin{abstract}
Objectives: Kingdom of Saudi Arabia (KSA) has experienced tremendous economic growth in the past few years and this in turn has led to undesirable lifestyle behaviors coupled with an associated rise in non-communicable diseases. This has forced the KSA administration to encourage sports related activities for a healthy life style. In this article, a Systematic Literature Review (SLR) is presented to discuss the current state of Physical Activity (PA) and sports activities in KSA and Other Countries in the World (OCW). The article also presents issues that hinder the success of physical and sports activities development in KSA to identify research gap. Methods: SLR search was conducted using ScienceDirect, Springer, Journal of health sciences and Google Scholar databases. The databases electronic search produced 553 articles at the initial stage. Some of these articles were eliminated since they did not conform to inclusion criteria. Finally a total of 58 articles satisfied the condition and were included for the study. Results: The literature highlighted that the studies investigating the male respondents is quite low having 3 in KSA and 0 in OCW, as against 7 in KSA and 0 in OCW for Females. In addition, the empirical analyses of the result based on this SLR concluded that the sports related studies in KSA are very low as compared to OCW. The study revealed that the main factors that hinder the success of physical and sports activities in KSA universities among males are lack of energy, motivation, self-confidence, and time, while among females, they are lack of social support and resources. Conclusion: It is not encouraged to participate in sports activity in Saudi Arabia. Despite the protests to promote sports activities there is very little action in this area as compared to OCW. Therefore, further research is needed to realize the potential in this area KSA to realise the vision 2030 and goal.
\end{abstract}

Keywords Physical and Sports Activities, the Current State of Sports, Issues, Health Promotion and KSA Vision 2030, University

\section{Introduction}

Some few years back, Citizens in the Kingdom of Saudi Arabia (KSA) had survived a simple life, as they were into many different PA by involving in consistent sports activities (Al-hazzaa, 2018). Sports promote active healthy living among them. The energetic healthiness can be realized with constant PA in the form of sports. Healthy living based on the simple life of KSA peoples were evident from support through government initiative and policies (Thompson, 2017). The KSA policy and plan target reduction of Saudi Arabia's dependence on oil, hence it diversifies their economy and develops public service sector towards good health care [3-4]. This is one, out of the many goals for vision 2030 plan. A study by (McWhannell, Triggs and Moss, 2017) acknowledged that "PA has a positive effect on academic performance for students in academic core subjects and executive function". The participants from School B remarked that they engage in PA simply to become healthy and stronger than those from participants from School A. The study revealed participation in sports activity makes the students have more fun (McWhannell, Triggs and Moss, 2017). The qualitative data explained that participant's perceptions of PA showed some similarities between schools $\mathrm{A}$ and $\mathrm{B}$. It was concluded that participants have different reasons for taking part in $\mathrm{PA}$, therefore, their perception to use the playground was given as an idea to improve PA (McWhannell, Triggs and Moss, 2017).

Also, (McPherson et al., 2018) supported the claims that PA has a significant effect on the academic performance of students at all levels of education. The study indicated that the relationship occurred from the mediating effect of cognition. The model tested, identified that PA with cognition has both a direct and indirect relationship on the academic performance of the student. Therefore, further studies that will utilize larger sample sizes are suggested to investigate important confounding factors such as gender, age, and ethnicity (McPherson et al., 2018). This finding supports the need to improve sports activities in Saudi Arabia 
Universities to align with vision 2030 and help to achieve the goal. Physical Activity (PA) is any real growth delivered by the firmness of skeletal muscles that results in a significant increment in caloric necessities over resting vitality consumption (Alahmed and Lobelo, 2018). Based on the World Health Organization (WHO) WHO, (2018) physical idleness is regarded as the fourth energetic danger factor for worldwide mortality (WHO, 2018) and is estimated to be $6 \%$ of the worldwide death rate (WHO, 2010). The continuous effort by KSA government and their Ministry of education for introduction of sports activities in the higher institutions in Saudi could be attributed to the knowledge gained from the successes recorded based on revenues in some countries across the world namely United States, United Kingdom, China to mention a few (Table 1).

Table 1. Global revenue comparison for indoor and outdoor sports activities (Statistica, 2019)

\begin{tabular}{cc}
\hline Top 5 beneficiary countries for indoor and outdoor sports \\
\hline United States & US\$36.256m \\
\hline China & US\$20.545m \\
\hline United Kingdom & US\$3.31m \\
\hline Japan & US\$2.956m \\
\hline South Korea & US\$2.093m \\
\hline Malaysia & US\$121m
\end{tabular}

In Saudi Arabia, 58.5\% of the Saudi grown-up populace were considered physically dormant (Alahmed and Lobelo,
2018). In the Kingdom of Saudi Arabia, the WHO observed that $57 \%$ of kids and $71 \%$ of adolescents were physically idle (Al-Hazzaa, 2010). Based on the national finding, 60\% of the whole Saudi Arabian population is physically latent $(\mathrm{MOH}$, 2013). Moreover, $90 \%$ sit successively for more than 2 hours every day (MOH, 2013). To counter this habit, wellbeing instruction awareness is needed through Primary Health Care (PHC) to energize people for doing some daily PA. This can be achieved as KSA government policies have encouraged PA through sports activities in primary, secondary and higher institutions in Saudis by funding researches in various institutions in the country (Alghanim and Alhamali, 2011)(minister of higher education, 2015)(Ababteen, 2012). Studies have reported that the doctor acknowledged PA to be a critical factor amongst the most dominant wellbeing advancing practices (Parks et al., 2003; Al-hazzaa, 2018)(Parks, Housemann and Brownson, 2003). PA diminishes the danger of diabetes, stroke, ischemic heart ailments, and colon diseases. It is likewise imperative for weight control and the counteractive action of fitness (Action, On and Activity, 2018). Besides, the study has demonstrated that PA through sports promotes psychological wellness by lessened nervousness, sadness, and stress (Al-hazzaa, 2004). Figure 1 shows the relationship between sports, exercise and PA. However, there are many researches on the investigation of sports activities in KSA and the world at large for the past few years. Only a few studies on sports activities investigation in KSA are available.

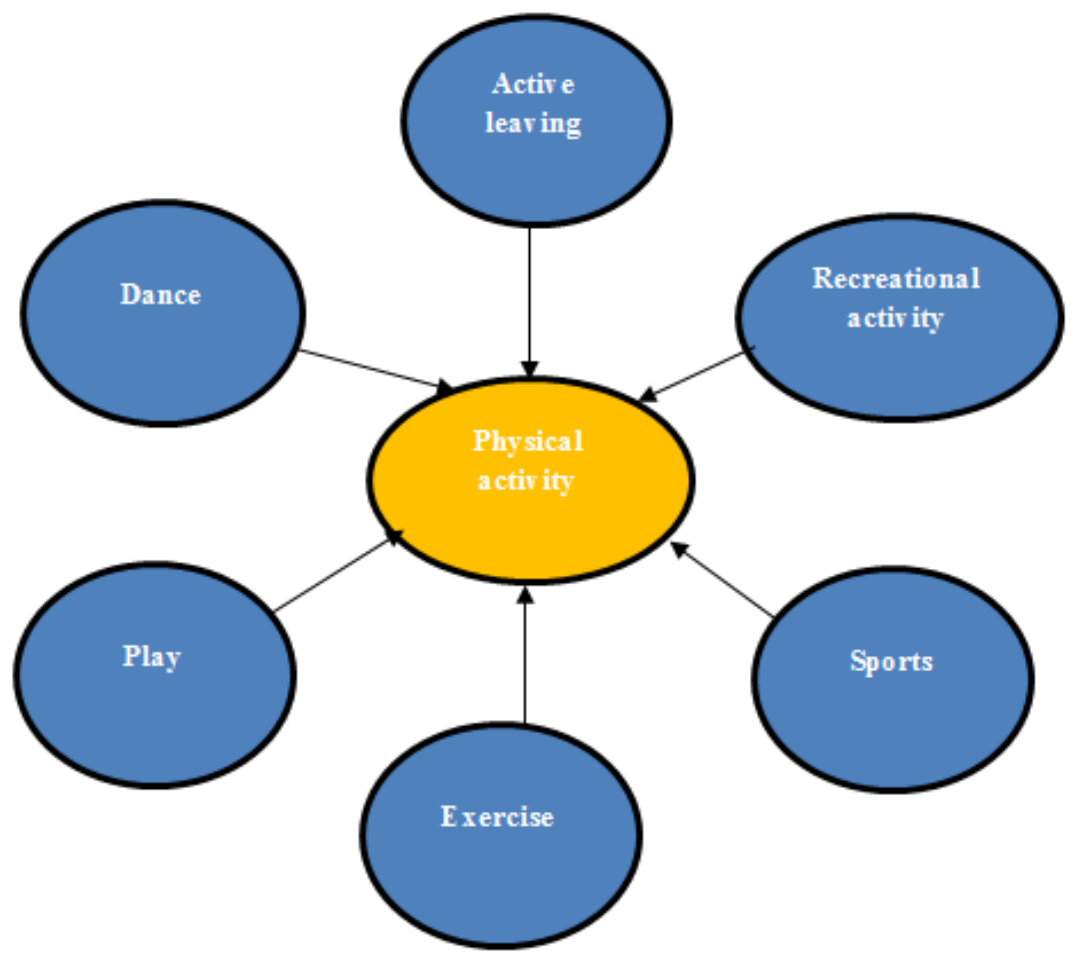

Figure 1. The relationship between sports, exercise and physical activity 


\subsection{Overview of the Problem}



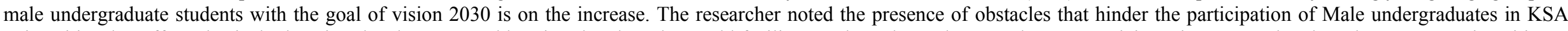

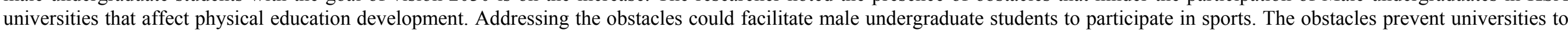

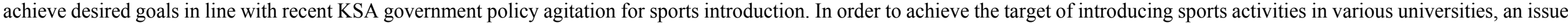

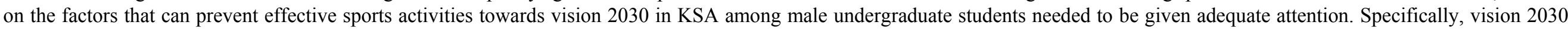



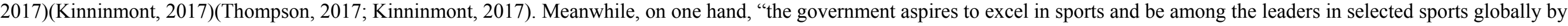
2030". Figure 2 shows the KSA vision 2030 plans which accommodate sports growth under CEDA.

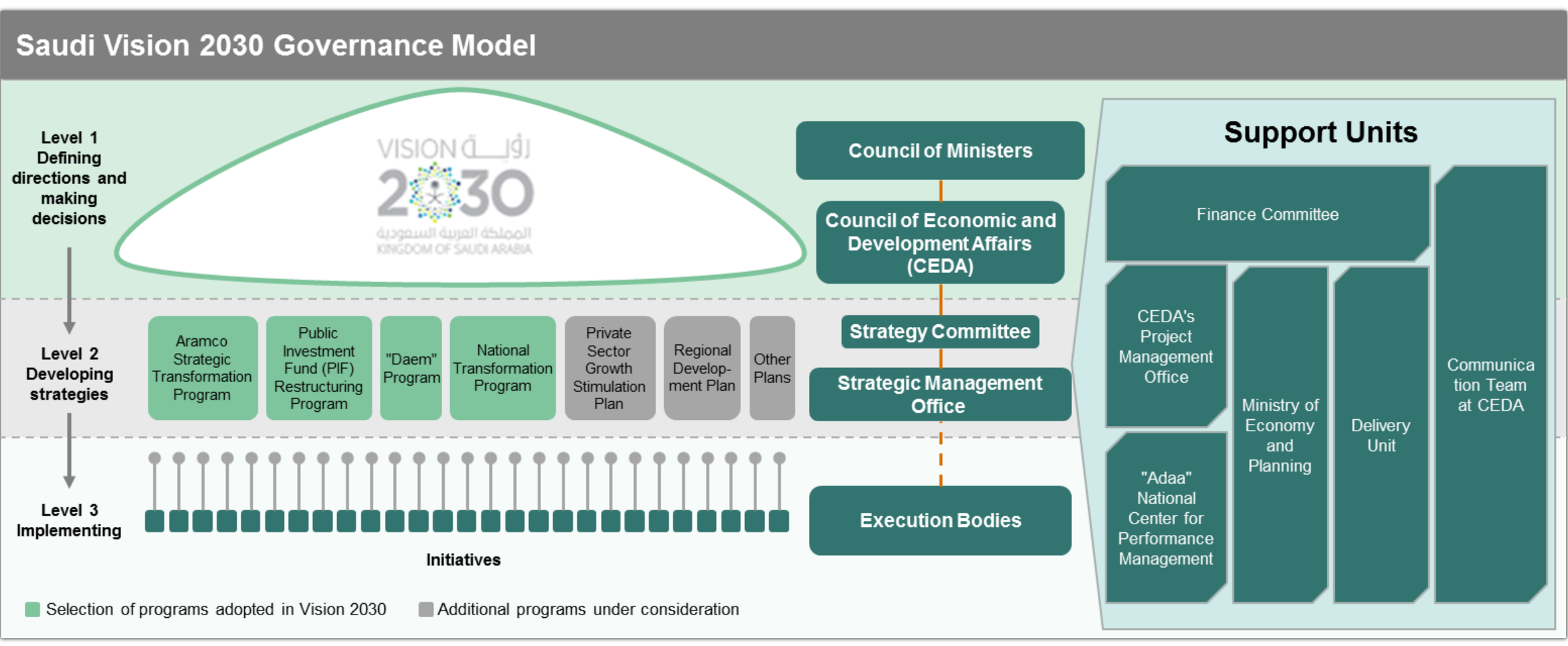

Figure 2. KSA vision governance model for achieving vision 2030 (Kinninmont, 2017) 


\subsection{Objectives of the Study}

This study focuses on achieving the following objectives:

1. Investigating the current state of sports activities in KSA universities compared to other countries in the world.

2. Investigation of the issues confronting the introduction of sports activities in KSA and compare it with other parts of the world.

\subsection{Research Questions}

In order to solve the problems, this paper intends to answer the following research questions (RQs):

1. What is the current state of sports activities in the Kingdom of Saudi Arabia (KSA) Universities and other countries?

2. What are the issues confronting the introduction of sports activities in KSA against the practice in other countries?

\section{Related Works}

Sports activity has a critical and fundamental role in all phases of life, particularly on adults. Sports activity has an important and irreplaceable role in all stages of life, especially in adolescence. However, the culture of physical exercising vary in certain periods of life and different environments such as countries and regions, rural or urban areas. (Cerar et al., 2017). Sports activity is a good pre-condition for the health, normal biological, and psychological development of young people. Constant and suitable sports activity maintains vitality, protect the human body against diseases and creates a better quality mature period of life. The curriculum of physical education facilitates learning for both children and young people about the importance of movement, sports, fitness activities and a healthy lifestyle. This practice offers significant leverage in the promotion of sports activities (Sancassiani, Machado and Preti, 2018). In view of the advancement of society, people moreover have an understanding of physical education. It plays a significant part in our everyday life. For instance, it makes a difference to improve our physical quality and mental wellbeing. Universities need to encourage physical education since the concept of education shows up in our life as a modern advancement for the new direction of contemporary sports. This can impact people's thought in their lifetime and provides vital esteem to the advancement of people and society (Al-Anon, 2018).

However, KSA people witnesses less access to exercising facilities and limited opportunities are available to engage in sports activity. School children and undergraduate students appear to have fairly good knowledge about the benefits of PA. On the contrary, a large percentage of these students are not properly informed about the skills on how to exercise or to be physically active. Most importantly, time constraint, low self-efficacy, lack of facilities or resources, and lack of social support are the major barriers to being physically active among Saudi Arabian populace (Al-Marzooqi, 2017).
Therefore, there is a need to investigate the factors that affect the healthy lifestyle and is a significant part of healthy living among Saudis youth. Especially undergraduate students boys do not have the understanding of the benefits of the Physical education. Past research on the barriers to sports activity among Saudi undergraduate students (boys), within different domains of sports activity (leisure time, occupational, transports, and households sports activity) have highlighted these issues among males (Al-Anon, 2018).

It was noted that a national policy encouraged active living and discouraged inactive life. Health-care providers have an important role to promote sports activity and encourage healthy lifestyle habits among all Saudi people. (Al-hazzaa, 2018). Apart from increased efforts to extend awareness about unhealthy lifestyle habits such as physical inactivity and harmful sedentary behaviors. Furthermore, there are urgent needs for reliable and widely disseminated information to the public for nutrition, physical activity and health, obesity prevention, and to live a long and active living. The spread of social media usage to the Saudi people can be fully utilized for physical activity promotion and obesity prevention. (Al-hazzaa, 2018). In addition, physical activity is positively related to a healthy quality of life ( Bjornson et al., 2008; Maali Saud Alsahli A, 2016; WHO, 2018). Most importantly, having recognized the effect of less physical inactive health among the populations, the World Health Congress (WHC) in 2004 suggested: "that the Member States should develop national physical activity action plans and policies to increase physical activity levels in their populations" (WHO, 2010; Al-Zalabani et al., 2015).

Consequently, a high rate of physical inactivity was reported in Kingdom of Saudi Arabia, similarly, further studies conducted in Riyadh revealed that younger age groups of physical inactivity levels ranged from $81 \%$ to $74.9 \%$ (Al-Zalabani et al., 2015). Despite the high rate of physical inactivity reported, for example, available data from a small number of studies according to Al-hazzaa, (2018) suggests a high prevalence between $43.3 \%-99.5 \%$ of physical inactivity among Saudi children and adults alike. However, no research to date has investigated current state and issues confronting introduction of sports activities in KSA universities despite government emphasis on the importance of sports for healthy lives and longer life span when practising on a regular basis (Eman et al., 2019). KSA government policy and Ministry of education have a broad plan including the campaign for sports activities in all institution having seen the benefits from different countries in the world as shown in Table 1 (Kinninmont, 2017).

\section{The Methodology Used and Data Search Criteria}

The search for the primary studies was done using kitchenam approach for this SLR. The search was conducted using Sciencedirect, Springer, Journal of health sciences and Google Scholar databases which help to obtain related thesis in the focus domain published till March 8, 2019(Alsolami, B., \& Embi, M. R., 2018). The keywords such as PA, Sports, 
physical inactivity, current state, Saudi Arabia university, Saudi Arabia citizens, male undergraduate students and issues confronting sports activities were used as search criteria by combining either of the words.

Apart from the electronic search, the selected article references were carefully examined manually and identified for inclusion as relevant papers in this search. The article written in English from literature was added as inclusion criteria. This comprised of Saudi able body of male undergraduate students, that can participate in sports from some selected universities among the 26 universities (Fahad, Ali and Ibrahim, 2016). The article included having a clear discussion on sports activities covering other parts of the world and those that emphasized KSA and conducted in the universities environment. The inclusive studies were carefully read and analyzed based on the preset criteria for analysing the articles. Any of the selected articles used for the primary studies that do not meet the criteria for inclusion are excluded.

\subsection{Extraction of Primary Data}

This section explain the information checked and recorded in order to conduct this study: The causes of physical inactivity, the current state of sports activities, resources available that can encourage male undergraduate students to participate in sports, issues confronting sports activities in KSA universities, the target participant numbers, average age of participants, the location where data collection was carried out, and whether the study was conducted at Saudia, or other countries.

The initial electronic search on the database yielded 553 articles. Titles and the abstracts of all articles were read and revised for exclusion and inclusion. Meanwhile, most of the articles were excluded because they did not conform to the inclusion criteria. The remaining relevant primary articles were 84 articles. This finally forms the choices for the systematic literature review screening in Figure 1. Fifteen (15) articles were excluded due to the duplication or shortfall of content needed. Out of the relevant 69 articles, 11 articles were excluded since they do not present clear explanation on the current state of sports activities in KSA or there are no good synthesis on the target participants used and issues that hinder the introduction of sports in KSA universities focused in the article. Therefore, the remaining selected articles included and eventually used for the proposed SLR added to 58 articles.

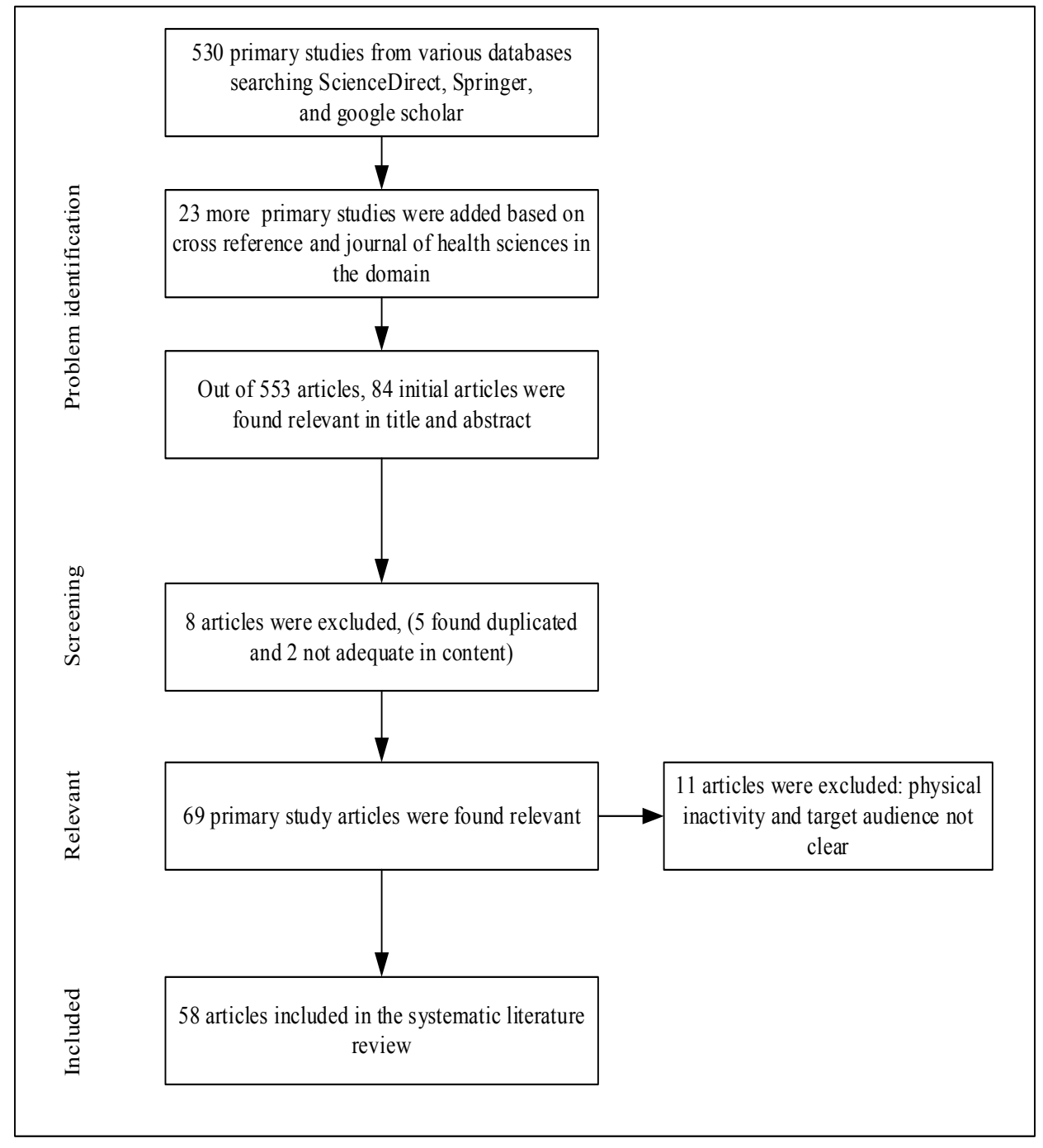

Figure 3. The flow process of SLR articles selection (Kitichenham, 2007). 


\section{Results of SLR}

In this section, the results of the systematic literature review are presented. Table 2 shows the current state of PA and sports activities in the Kingdom of Saudi Arabia (KSA); while Table 3 presents similar results for PA and sports from other countries in the world by publications. Numbers of publication by years from 2013 to 2019 are shown in Figure 4, while Figure 5 illustrates the country with the most frequent research contributions from the primary studies summarized in Figure 3. Out of the studies in Table 2, only 3 focused on males, 5 on females. Out of the remaining studies, 5 focused on both males and females while 7 did not indicate the categories utilized for their data collection and analyses. As clearly seen from Table 2 not too many studies conducted on sports alone were found from KSA researchers. In fact, those few published articles related to sports was just published recently within 3 years ago specifically in 2016 and 2018 respectively. Conversely, the articles published related to sports were more in other parts of the world notably about 13 since the year 2014 until the year 2019 as shown in Table 3.

Table 2. The current state of PA and sports activities in the Kingdom of Saudi Arabia

\begin{tabular}{|c|c|c|c|c|c|c|c|c|}
\hline SN. & $\begin{array}{c}\text { Data } \\
\text { description }\end{array}$ & Region or city & $\begin{array}{l}\text { Gender/ } \\
\text { age }\end{array}$ & $\begin{array}{c}\text { Target } \\
\text { audience } \\
\text { sample size }\end{array}$ & $\begin{array}{l}\text { Sports } / \mathbf{P} \\
\text { A activity }\end{array}$ & $\begin{array}{l}\text { Inactive } \\
\text { level (\%) }\end{array}$ & Criteria & Method \\
\hline 1 & $\begin{array}{c}\text { Attitude } \\
\text { towards PA } \\
\text { (Jifri, 2013) }\end{array}$ & Jeddah, KSA & N/A & 275 & PA & N/A & Set of procedure & $\begin{array}{c}\text { Descriptive } \\
\text { survey }\end{array}$ \\
\hline 2 & $\begin{array}{l}\text { The obstacle } \\
\text { that faces } \\
\text { physical } \\
\text { education } \\
\text { (Abedalhafiz, } \\
\text { 2013) }\end{array}$ & $\begin{array}{c}\text { Al-Madinah, } \\
\text { Al-munawarah, } \\
\text { KSA }\end{array}$ & $\begin{array}{c}\text { Males } \\
\text { and } \\
\text { Females }\end{array}$ & 187 & $\begin{array}{l}\text { Obstacle } \\
\text { to PA }\end{array}$ & N/A & $\begin{array}{c}\text { An obstacle in } \\
\text { physical } \\
\text { education }\end{array}$ & $\begin{array}{c}\text { Descriptive } \\
\text { questionnaire }\end{array}$ \\
\hline 3 & $\begin{array}{l}\text { Health-related } \\
\text { to the quality } \\
\text { of life (QOL) } \\
\text { through } \\
\text { physical } \\
\text { activity level } \\
\text { (PAL) } \\
\text { (El-sobkey, } \\
\text { 2014) }\end{array}$ & Riyadh, KSA & N/A & 100 & $\begin{array}{l}\text { PA \& } \\
\text { QOL }\end{array}$ & $\begin{array}{l}\text { Higher } \\
\text { PAL } \\
\text { improve } \\
\text { health }\end{array}$ & General health & $\begin{array}{l}\text { Short form } \\
\text { health status } \\
\text { survey }\end{array}$ \\
\hline 4 & $\begin{array}{l}\text { Assessment of } \\
\text { PA inactivity } \\
\text { (Awadalla et } \\
\text { al., 2014) }\end{array}$ & $\begin{array}{c}\text { South-western, } \\
\text { KSA }\end{array}$ & $\begin{array}{l}\text { Males \& } \\
\text { Females }\end{array}$ & 1257 & $\begin{array}{c}\mathrm{PA} \\
\text { inactivity }\end{array}$ & $87.9 \%$ & $\begin{array}{c}\text { Predictor of PA } \\
\text { inactive }\end{array}$ & Questionnaire \\
\hline 5 & $\begin{array}{l}\text { Physical } \\
\text { activity and } \\
\text { quality of life } \\
\text { (Ali et al., } \\
\text { 2015) }\end{array}$ & Abha, KSA & N/A & 400 & PA & $70.3 \%$ & Low PA & $\begin{array}{l}\text { Short-form } \\
\text { study }\end{array}$ \\
\hline 6 & $\begin{array}{c}\text { Participation } \\
\text { Motive } \\
\text { (Antony } \\
\text { Tomar, 2015) } \\
\end{array}$ & Damman KSA & N/A & 1039 & $\begin{array}{l}\text { PA and } \\
\text { sports }\end{array}$ & N/A & $\begin{array}{l}\text { Competence } \\
\text { factor }(3.419)\end{array}$ & Questionnaire \\
\hline 7 & $\begin{array}{l}\text { Risk factors for } \\
\text { PA inactivity } \\
\text { (Assiri et al., } \\
\text { 2015) }\end{array}$ & $\begin{array}{c}\text { Khamis } \\
\text { mushayt, KSA }\end{array}$ & $\begin{array}{l}\text { Males } \\
30-44\end{array}$ & 400 & $\begin{array}{c}\mathrm{PA} \\
\text { inactivity }\end{array}$ & $43-99 \%$ & Risk & Questionnaire \\
\hline 8 & $\begin{array}{l}\text { BMI with diet } \\
\text { and physical } \\
\text { activity } \\
\text { (Majeed, 2015) }\end{array}$ & Damman KSA & Females & 215 & PA & N/A & $\begin{array}{c}\text { Diet and weight } \\
\text { management }\end{array}$ & Questionnaire \\
\hline 9 & $\begin{array}{c}\text { Facilities } \\
\text { impediment to } \\
\text { PA } \\
\text { (Samara et al., } \\
\text { 2015) }\end{array}$ & Riyadh, KSA & Females & 94 & PA & N/A & $\begin{array}{c}\text { Different } \\
\text { parameters } \\
\text { exploration }\end{array}$ & $\begin{array}{c}\text { Questionnaire } \\
\text { stratified } \\
\text { sampling }\end{array}$ \\
\hline 10 & $\begin{array}{c}\text { Behavior } \\
\text { predictors } \\
\text { (Al-Sobayel et } \\
\text { al., 2015) }\end{array}$ & KSA & $\begin{array}{l}\text { Males \& } \\
\text { Females }\end{array}$ & 2888 & PA & N/A & $\begin{array}{l}\text { Gender } \\
\text { difference }\end{array}$ & $\begin{array}{l}\text { Multi-stage and } \\
\text { random } \\
\text { sampling }\end{array}$ \\
\hline 11 & $\begin{array}{l}\text { Assessment } \\
\text { and reason for } \\
\text { participation in } \\
\text { PA (Alsubaie }\end{array}$ & Riyadh, KSA & Males & 453 & PA & N/A & $\begin{array}{c}\text { Health - } \\
\text { enhacement }\end{array}$ & Questionnaires \\
\hline
\end{tabular}




\begin{tabular}{|c|c|c|c|c|c|c|c|c|}
\hline & $\begin{array}{l}\text { and Omer, } \\
\text { 2015) }\end{array}$ & & & & & & & \\
\hline 12 & $\begin{array}{c}\text { The prevalence } \\
\text { of PA } \\
\text { (Al-zalabani } \\
\text { and } \\
\text { Al-hamdan, } \\
\text { 2015) }\end{array}$ & KSA & N/A & 4758 & PA & $\begin{array}{l}85.6 \% \\
\text { male. } \\
90.2 \%\end{array}$ & $\begin{array}{l}\text { Level of PA } \\
\text { correlation }\end{array}$ & $\begin{array}{c}\text { Global PA } \\
\text { Questionnaire } \\
\text { (GPAQ) }\end{array}$ \\
\hline 13 & $\begin{array}{l}\text { Barriers to PA } \\
\text { (Alsahli, 2016) }\end{array}$ & $\begin{array}{l}\text { Hafr-Al batin, } \\
\text { KSA }\end{array}$ & Females & 211 & PA & N/A & Brriers & Questionnaires \\
\hline 14 & $\begin{array}{l}\text { Constraints in } \\
\text { PA and sports } \\
\text { (Alahmad, } \\
\text { 2016) }\end{array}$ & Riyadh, KSA & Males & 909 & $\begin{array}{c}\text { Sports and } \\
\text { PA }\end{array}$ & $74 \%$ & $\begin{array}{c}\text { Constraints and } \\
\text { motivation }\end{array}$ & Questionnaires \\
\hline 15 & $\begin{array}{l}\text { Factors and PA } \\
\text { (Elzawi et al., } \\
2017)\end{array}$ & Jazan, KSA & $\begin{array}{l}\text { Males } \\
\text { and } \\
\text { females }\end{array}$ & 419 & PA & $43-99.5 \%$ & $\begin{array}{c}\text { Fcators } \\
\text { affecting PA }\end{array}$ & Questionnaires \\
\hline 16 & $\begin{array}{l}\text { PA of young } \\
\text { girls (Aljaaly, } \\
2017)\end{array}$ & Jeddah, KSA & Females & 1519 & PA & $56.8 \%$ & PA assessment & Questionnaires \\
\hline 17 & $\begin{array}{c}\text { Inactive } \\
\text { prevalence and } \\
\text { perceived } \\
\text { barrier to } \\
\text { active living } \\
\text { (Al-hazzaa, } \\
\text { 2018) }\end{array}$ & Riyadh, KSA & N/A & 434 & $\begin{array}{c}\text { PA } \\
\text { inactive }\end{array}$ & N/A & $\begin{array}{l}\text { Prevalent and } \\
\text { perceived } \\
\text { barrier }\end{array}$ & $\begin{array}{c}\text { Systematic } \\
\text { review } \\
\text { Medline and } \\
\text { Google scholar }\end{array}$ \\
\hline 18 & $\begin{array}{l}\text { University } \\
\text { activity } \\
\text { management } \\
\text { (Al-Anizi, } \\
\text { 2018) }\end{array}$ & Riyadh, KSA & N/A & $\begin{array}{c}\text { Not } \\
\text { specified }\end{array}$ & $\begin{array}{l}\text { Sports } \\
\text { activity }\end{array}$ & N/A & $\begin{array}{c}\text { Enhancing } \\
\text { intellectual } \\
\text { security }\end{array}$ & Descriptive \\
\hline 19 & $\begin{array}{l}\text { Participation } \\
\text { among women } \\
\text { (Fallatah et al., } \\
\text { 2019) }\end{array}$ & Makkah, KSA & Females & 190 & PA & N/A & $\begin{array}{l}\text { Protection of } \\
\text { female }\end{array}$ & Mixed survey \\
\hline 20 & $\begin{array}{l}\text { Related risk } \\
\text { factors (Issn, } \\
\text { 2019) }\end{array}$ & Jouf, KSA & Females & 200 & PA & N/A & $\begin{array}{c}\text { Obesity-related } \\
\text { risks }\end{array}$ & Questionnaires \\
\hline
\end{tabular}

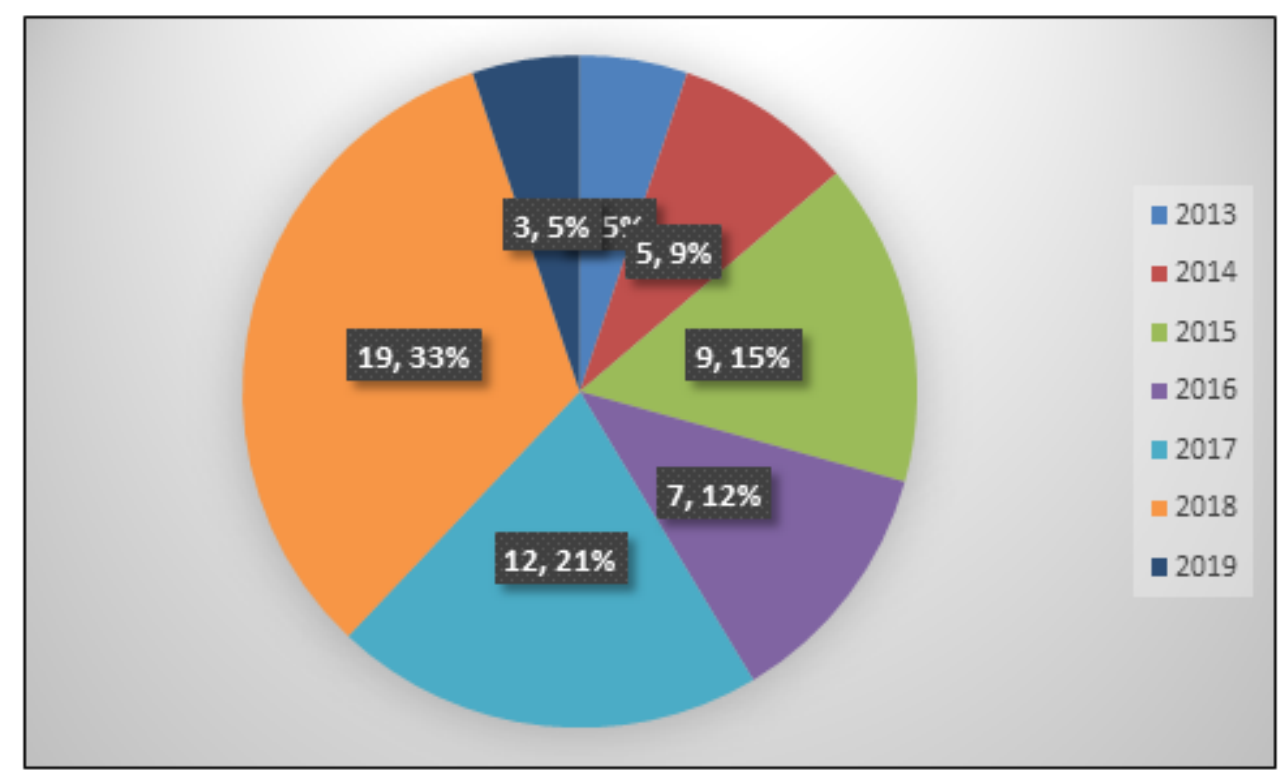

Figure 4. Summary of SLR primary studies by years of publication 


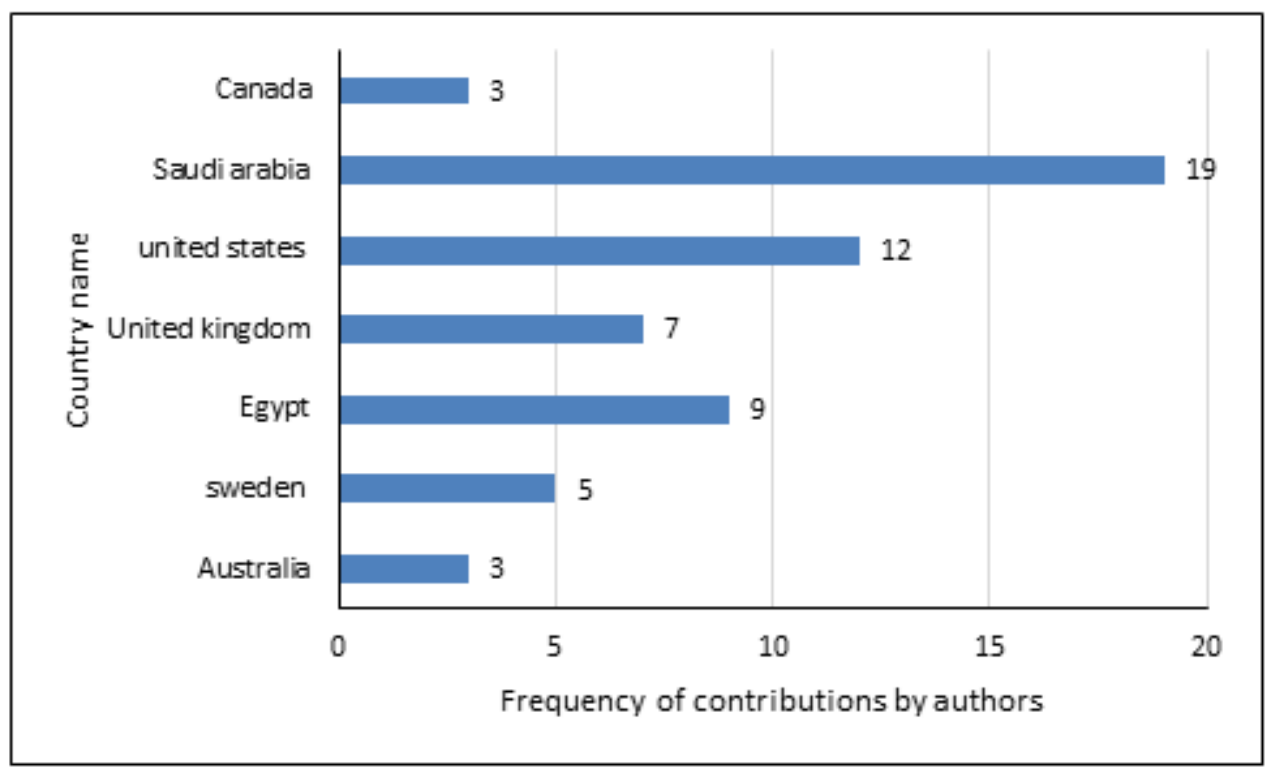

Figure 5. Summary SLR on physical and sports activities authors contributions by affiliations country from selected studies

Table 3. The current state of PA and sports activities from other countries in the world

\begin{tabular}{|c|c|c|c|c|c|c|c|c|}
\hline SN. & $\begin{array}{c}\text { Data } \\
\text { description }\end{array}$ & Region or city & Gender/age & $\begin{array}{c}\text { Target } \\
\text { audience } \\
\text { sample } \\
\text { size }\end{array}$ & $\begin{array}{c}\text { Sports/PA } \\
\text { activity }\end{array}$ & $\begin{array}{c}\text { Inactive } \\
\text { level } \\
(\%)\end{array}$ & Criteria & Method \\
\hline 1 & $\begin{array}{c}\text { Physical } \\
\text { inactivity and } \\
\text { factors } \\
\text { (Azuhairi, 2014) }\end{array}$ & $\begin{array}{l}\text { Selangor, } \\
\text { Malaysia }\end{array}$ & $\begin{array}{l}\text { Males and } \\
\text { females }\end{array}$ & 894 & Sports & $41.4 \%$ & $\begin{array}{l}\text { Physical } \\
\text { inactivity } \\
\text { among } \\
\text { university } \\
\text { student }\end{array}$ & Questionnaires \\
\hline 2 & $\begin{array}{c}\text { Effects of } \\
\text { participation in } \\
\text { School sports } \\
\text { (Van et al., } \\
\text { 2016) }\end{array}$ & Minnesota-USA & N/A & 12.849 & Sports & $\mathrm{N} / \mathrm{A}$ & $\begin{array}{c}\text { Sports } \\
\text { encouragement }\end{array}$ & N/A \\
\hline 3 & $\begin{array}{l}\text { Lack of sports } \\
\text { equipment as } \\
\text { constraints } \\
\text { (Bamidele et al., } \\
\text { 2016) }\end{array}$ & Kogi, Nigeria & N/A & 1315 & Sports & N/A & $\begin{array}{l}\text { Constraints on } \\
\text { sport equipment }\end{array}$ & Questionnaires \\
\hline 4 & $\begin{array}{l}\text { Barriers to } \\
\text { physical activity } \\
\text { (Tong et al., } \\
\text { 2016) }\end{array}$ & Kuwait & $\begin{array}{l}\text { Males and } \\
\text { females }\end{array}$ & 1123 & PA & N/A & $\begin{array}{c}\text { Percieved } \\
\text { bariers to PA }\end{array}$ & Questionnaires \\
\hline 5 & $\begin{array}{c}\text { Physical } \\
\text { Activity Patterns } \\
\text { (Clemente et al., } \\
\text { 2016) }\end{array}$ & Portugal & $\begin{array}{l}\text { Males and } \\
\text { females }\end{array}$ & 126 & PA & N/A & $\begin{array}{l}\text { Promote PA } \\
\text { among the } \\
\text { populace }\end{array}$ & $\begin{array}{c}\text { Wearing of an } \\
\text { accelerometer } \\
\text { for } 7 \text { days }\end{array}$ \\
\hline 6 & $\begin{array}{l}\text { Influence of } \\
\text { sports } \\
\text { participation } \\
\text { (Munoz-bullion } \\
\text { et al., 2017) }\end{array}$ & Spain & N/A & 3,671 & Sports & N/A & $\begin{array}{l}\text { Sporting } \\
\text { activities }\end{array}$ & Questionnaires \\
\hline 7 & $\begin{array}{l}\text { Engaging in } \\
\text { sports (Cerar et } \\
\text { al., 2017) }\end{array}$ & Slovenia & $\begin{array}{l}\text { Males and } \\
\text { females }\end{array}$ & 5271 & Sports & N/A & $\begin{array}{c}\text { Increase in } \\
\text { sports becomes } \\
\text { national priority }\end{array}$ & Questionnaires \\
\hline 8 & $\begin{array}{c}\text { Relation and } \\
\text { Sports } \\
\text { Participation } \\
\text { (Support et al., } \\
\text { 2018) } \\
\end{array}$ & Pakistan & $\begin{array}{l}\text { Males and } \\
\text { females }\end{array}$ & 248 & $\begin{array}{l}\text { Sports } \\
\text { activity }\end{array}$ & N/A & $\begin{array}{l}\text { Relation } \\
\text { betewwen } \\
\text { sports } \\
\text { participation }\end{array}$ & Questionnaires \\
\hline 9 & $\begin{array}{c}\text { Physical } \\
\text { Inactivity in } \\
\text { Adolescent } \\
\text { Students }\end{array}$ & Brazilian & $\begin{array}{l}\text { Males and } \\
\text { females }\end{array}$ & 1391 & $\begin{array}{l}\text { Physical } \\
\text { inactivity }\end{array}$ & N/A & $\begin{array}{c}\text { Factors } \\
\text { responsible for } \\
\text { physical } \\
\text { inactivity }\end{array}$ & Questionnaires \\
\hline
\end{tabular}




\begin{tabular}{|c|c|c|c|c|c|c|c|c|}
\hline & $\begin{array}{c}\text { (Michael et al., } \\
\text { 2018) }\end{array}$ & & & & & & & \\
\hline 10 & $\begin{array}{c}\text { Culture on } \\
\text { sports } \\
\text { achievements } \\
\text { (Sulistiyono et } \\
\text { al., 2018) } \\
\end{array}$ & Indonesia & N/A & N/A & Sports & $\mathrm{N} / \mathrm{A}$ & $\begin{array}{c}\text { More } \\
\text { synchronized } \\
\text { policy is } \\
\text { encourage }\end{array}$ & $\begin{array}{l}\text { Structured } \\
\text { interview }\end{array}$ \\
\hline 11 & $\begin{array}{c}\text { Salient belief } \\
\text { to participate in } \\
\text { sports (Quinton, } \\
\text { 2018) }\end{array}$ & British & N/A & 76 & Sports & N/A & $\begin{array}{l}\text { Salient belief } \\
\text { for recreational } \\
\text { sports }\end{array}$ & Questionnaires \\
\hline 12 & $\begin{array}{l}\text { Effect of school } \\
\text { sports facilities } \\
\text { (Davida et al., } \\
\text { 2018) }\end{array}$ & British & $\begin{array}{l}\text { Males and } \\
\text { females }\end{array}$ & 17634 & Sports & N/A & $\begin{array}{c}\text { Sports facilities } \\
\text { inadequacy }\end{array}$ & Questionnaires \\
\hline 13 & $\begin{array}{l}\text { Current situation } \\
\text { of students } \\
\text { sports life (Yan } \\
\text { and Ma, 2018) }\end{array}$ & China & $\begin{array}{l}\text { Males and } \\
\text { females }\end{array}$ & 94 & Sports & $\mathrm{N} / \mathrm{A}$ & $\begin{array}{c}\text { Analyzing } \\
\text { student sports } \\
\text { participation }\end{array}$ & $\begin{array}{l}\text { Questionnaires } \\
\text { and LR }\end{array}$ \\
\hline 14 & $\begin{array}{l}\text { Sports and } \\
\text { exercise at } \\
\text { university } \\
\text { (Castaneda et } \\
\text { al., 2018) } \\
\end{array}$ & Spain & $\begin{array}{l}\text { Males and } \\
\text { females }\end{array}$ & 1085 & Sports & N/A & $\begin{array}{c}\text { Correlation } \\
\text { between gender }\end{array}$ & Questionnaires \\
\hline 15 & $\begin{array}{l}\text { Physical activity } \\
\text { promotion } \\
\text { (Kosowan et al., } \\
\text { 2019) }\end{array}$ & Manitoba & N/A & 54 & PA & $\mathrm{N} / \mathrm{A}$ & $\begin{array}{l}\text { Faciliate } \\
\text { enhance PA }\end{array}$ & $\begin{array}{l}\text { Qualitative and } \\
\text { quantitative }\end{array}$ \\
\hline 16 & $\begin{array}{l}\text { Quantitative } \\
\text { sport places } \\
\text { (Alizadeh, } \\
\text { 2019) }\end{array}$ & Tajikistan & N/A & 19 & Sports & $\mathrm{N} / \mathrm{A}$ & $\begin{array}{l}\text { Quantifying } \\
\text { sport spaces }\end{array}$ & $\begin{array}{l}\text { Qualitative and } \\
\text { quantitative }\end{array}$ \\
\hline 17 & $\begin{array}{l}\text { Correlation in } \\
\text { PA and medical } \\
\text { students } \\
\text { (Yousif and } \\
\text { Kaddam, 2019) }\end{array}$ & Sudan & N/A & 216 & PA & $44.9 \%$ & $\begin{array}{c}\text { The } \\
\text { relationship } \\
\text { between PA and } \\
\text { obesity among } \\
\text { medical } \\
\text { students } \\
\end{array}$ & Questionnaires \\
\hline 18 & $\begin{array}{c}\text { Importance of } \\
\text { sports activities } \\
\text { (Di-palma et al., } \\
\text { 2019) }\end{array}$ & Italy & N/A & N/A & Sports & N/A & N/A & Not specified \\
\hline 19 & $\begin{array}{l}\text { Anxiety among } \\
\text { students in } \\
\text { sports (Profile, } \\
\text { 2019) }\end{array}$ & Turkey & $\begin{array}{l}\text { Males and } \\
\text { females }\end{array}$ & 780 & Sports & N/A & $\begin{array}{l}\text { Analysing test } \\
\text { anxiety }\end{array}$ & Questionnaires \\
\hline 20 & $\begin{array}{l}\text { Effect of school } \\
\text { sports facilities } \\
\text { (Black et al., } \\
\text { 2019) }\end{array}$ & Britain & $\begin{array}{l}\text { Males and } \\
\text { females }\end{array}$ & 17634 & Sports & N/A & $\begin{array}{l}\text { Sports facilities } \\
\text { effect on school }\end{array}$ & $\begin{array}{l}\text { Secondary data } \\
\text { from the } \\
\text { National Child } \\
\text { Development } \\
\text { Study (NCDS) }\end{array}$ \\
\hline
\end{tabular}

Figure 5 shows the trend in studies conducted in this area from well-known databases like Scopus with the highest number of publications by the country as on March 2nd 2019, as the databases were accessed on this date. It was observed that researchers in Saudi Arabia were found to be the highest for research related to sports activities and PA with 221 publications, followed by the United States having 46 and least number of publication 1 for Ukraine. 




Figure 6. Snapshot of publications analysis by researchers' affiliation accessed 2/3/2019 


\subsection{The Current State of Sports Activities}

Trends for continuous development in society revealed an understanding of physical education and its importance in our daily life. Physical education which serves as the origin for PA and sports improve physical quality, mental stability and healthy life. The Commonwealth Secretariat advocated for use of sport as a tool in advancing sustainable development and strengthening governance, gender equality and the protection and promotion of human rights in sport (SFD, 2017). In addition to that, in 2016, Mauritius proposed a sport's plan, by allocating funding and resources to encourage Mauritians participation in sports and PA (SFD, 2017). Similarly, in Zambia the same year 2016, the sport was used to promote physical and mental health to support education, by boosting employment prospects and improving social cohesion (SFD, 2017). In the same vein, Botswana has engaged in a sport to promote gender equality through the production of national guidelines and strategy for gender mainstreaming in sport (SFD, 2017). In Sierra Leone, Sport for Development and Peace (SDP) strategy was embraced to enhance the role of sport to improve the lives of young people to build them stronger since 2016 (SFD, 2017). The countries enumerated above, have embraced the sport activites and realised its benefits. Malaysia is also not left out among other giant countries in the world with global annual revenue amounted to one hundred and twenty-one million us dollar (US\$121m) presented in Table 1. However, participation in sports activities can stimulate people's thought in a lifetime. This also can contribute important value to the development of individuals and society (Anon, 2018). Consequently, from Table 2 fewer studies were conducted on sports at the same time it was generally noticed that research that focuses on the investigation of male undergraduate students was rarely found. It has been established that implementation of Non-communicable diseases (NCDs) and prevention program in KSA can only be achieved through recent and valid data collection to further ascertain the prevalence of physical inactivity, trends and barriers. This will help to determine the status of citizens; however, this will involve policy makers, health care authorities and higher institutions through regular research as encouraged by KSA government (Al-hazzaa, 2002).

In the past years, KSA has enjoyed enormous economic growth and prosperity. This was possible by the technological transformation that foster negative changes in lifestyle (Al-hazzaa, 2018). Thereafter, physical inactivity, sedentary behaviors, consumption of caloric dense diet, and sugar-sweetened beverages suddenly increased and became predominant among KSA society. According to a national survey, $60 \%$ of the entire Saudi Arabian population is physically inactive (Alhamed and Lobelo, 2018). Furthermore, 90\% sit consecutively for more than 2 hour daily (Alhamed and Lobelo, 2018). This further aggravated lifestyle-related Non - communicable diseases (NCD's) in the country, which includes, obesity, diabetes mellitus, coronary artery diseases and hypertension (Lee et al., 2012). Despite the high rate of physical inactivity reported, for example, available data from a small number of studies according to Al-hazzaa, (2018) suggests a high prevalence between $43.3 \%-99.5 \%$ of physical inactivity among Saudi children and adults alike. However, no research to date has investigated the current state of sports activities in Saudi Arabia Universities for male undergraduates students against other countries (Eman et al., 2019). Saudi Arabia has a wide-ranging plan as observed in (Kinninmont, 2017). The purpose of the extensive plan according to Kinninmont, (2017) is to provide an alternative to KSA's economy and reduce its dependency on oil. Basically, one of the major economic strategies of KSA as part of the plan is youth and sports initiatives (Kinninmont, 2017). This serves as useful functions and personal branding projects to boost the country's national policies. In view of this, further research is desirable. There is indisputable evidence in many studies repeating the benefits of sport activities and sports on health (Celis-morales et al., 2015; Donnelly et al., 2013; Fanning et al., 2018; Kelley, Kelley, Roberts, \& Haskell, 2012; Nakamura et al., 2014; Song et al., 2012). Also, the general public is currently alert of the significance of active participation in sport to optimize their bodies' performance at all levels. Recent research on the sports related habits of the Spanish has underlined a rising interest in undertaking sports activities and benefits derivable from the sport (García-Ferrando \& Llopis-Goig, 2010; Ministerio de Educación Cultura y Deporte, 2015). Similarly, a new conception of sport, orientation for improvement on quality lifestyle has been considered over the last decade by Spanish. The same surveys identify that sporting activity has moved from competitive sport towards healthier ways of using one's free time. This is done, by including sport within healthier lifestyles. In order to function and assume the role of educational institutions, Spanish universities have tasked themselves the objective of promoting the sport at university. This is actualized by facilitating sports for the student community and, giving consideration to offer a compatible platform for students' academic commitments (Castañeda-Vázquez et al., 2018). According to CSD, (2010) sport in university is necessary for two main reasons which include; university as the final stage in people's education, university is the last chance to reinforce habits to improve quality of life and sport activities contributed to the development of an integral education for students (CSD, 2010).

\subsection{Issues Confronting Success of Sports Activities}

According to HP, (2015) since 2015, it has been reported that KSA government and World Health Organization (WHO) have strategies on ways to efficiently enhance public health condition in Saudi to address the lingering issues namely; physical inactivity among Saudi citizens, incidences of non-communicable diseases prevalent in the country, mental health and substance abuse due to less involvement in sports activities.

It is amazing to note that previous studies (Al-hazzaa, 2018)(Black et al., 2019) acknowledged that the proportion of Saudi children and adults at risk for inactivity exceeded the number at risk for any other traditional coronary heart diseases risk factors (Al-Hazzaa, 2018). Also worthy of note is that there exists a high prevalence of inactivity in KSA 
from females, this constitutes a major burden to public health due to more number of obesity (Al-Hazzaa, 2018). This is not the case when compared with men, Saudi women suffer from low exercising facilities, this is because they have less opportunity to engage in PA (Al-Hazzaa, 2018).

HP, 2015 asserted that one of the issues caused by inactive participation as observed among KSA citizens in sport is the frequent spread of NCDs. However, up till now, there is no primary health care that can address the problem. "For instance, in the country, there is an increase in childhood obesity which is affecting approximately $6-10 \%$ of preschool and school-age children" (HP, 2015). According to (Alsahli Maali Saud, 2016) Saudi female university students experienced a lack of sports facilities and university support as a major setback. This contributed to the loss of interest on the part of the students (Alsahli Maali Saud, 2016). The country is in the process of combating lifestyle risk factors by addressing physical inactivity (HP, 2015).

In the study of Jifri (2013), there were significant differences in health aspects based on sex variable in favour of male students from the result recorded. The study suggested that to arrest and strengthen students attitudes at King Abdulaziz University for physical activities a set of procedures such as lectures, newsletters and educational workshops is desirable for smooth implementation of effective sports activities.

According to (Al Anizi, 2018) none availability of sports activities in Saudi universities undermine youth energies, thus, encourages laziness on the part of the students. This practice is not good enough and it requires a proactive intervention of various university authorities, the ministry of education to embrace the KSA government sensitization towards discouraging physical inactivity for improvement of students health and wellbeing in KSA universities (Al-Anizi, 2018). In another study, it was reaffirmed that the main barriers to physical activity are; time limitation and lack of accessible and suitable sporting environment in some universities (El Gilany et al., 2011). In order to overcome these barriers consideration of students'view is a necessity to enhance the level of physical activity, for the selection of sports activities. In this situation students, interest plays an important role in setting their goal for the best choice of activities unsystematically. On the contrary, when consideration was not given, the result lacks enjoyment that ends up in terminating the engagement in the sports activity (Fortes et al., 2010).

The tendency to identify factors associated with the external dimensions of motivation from among universities students to determine (disease prevention, physical fitness, body weight management, physical appearance, and stress management is an important issue (Cerar et al., 2017).

According to (Guedes et al., 2013) key, motivational factors for exercise is achievable through self-determination theory. The study pointed out that the students are more difficult in adhering to exercise in a more effective and lasting way, as they prioritize factors associated with extrinsic motivation. Extrinsic motivation is useful for professionals who work in the areas of physical education and public health, as they provide resources that help to develop physical exercise programs in the university environment. These actions facilitate the level of motivation according to the EMI-2 dimensions (Guedes et al., 2013).

According to (Antony and Tomar, 2015) students improve on their competence, enjoyment or interest by involving in sports to optimize their physical well-being with the progression of educational levels. The infrastructural facilities needed for physical activities has not been optimized to the advantage of undergraduate students (Antony and Tomar, 2015). The need for the research related to optimization of the social experience of students and need for strategies to reduce the gap in socialization among students is evedient (Antony and Tomar, 2015).

Sports activities have a vital and unique role at all stages of life, particularly in the adult. The habits of physical exercising are different in certain stages of life depending on the environment for instance; countries, regions, rural or urban areas. (Cerar et al., 2017).

Regular sports activity maintains vitality, protects individual against diseases and creates a better quality for a complete life. A significant influence in the advancement of sports activities can be realized through the proper curriculum of physical education in which children and young people learn about the importance of movement, sport, fitness activities and a healthy lifestyle (Cerar et al., 2017). In view of the highlighted issues which focus on lack of suitable factors, adequate facilities in KSA universities responsible for continuous physical inactivity suggest further research for effective introduction of sports activities KSA with a thorough investigation that will offer a lasting solution capable of supporting Saudi government policy and awareness of sports necessity by the Ministry of Education.

\subsection{Reason for Poor Participation in Sports Activities}

Generally, in KSA among adults, it was noted that physically active is geared towards the maintenance of health and loss of weight. However, time constraints and unavailability of spaces and facilities are major factors discovered for not being physically active (Van et al., 2016; Cerar et al., 2017; Al-hazzaa, 2018; Black et al., 2019). In addition to that, it was reported in the study of Black et al., (2019) that adults who attended health centre considered the barriers to PA in males to be lack of energy, motivation, self-confidence, and time, while among females it was lack of social support and resources. Notably, attendance of school with inadequate facilities for sports constitutes a major setback for the likelihood of adult in the ages of 33, 42 and 50 not taking part in exercise (Black et al., 2019).

The KSA has experienced a dramatic increase in physical inactivity, with women having higher levels of inactivity than men among all age groups (Samara et al., 2015). This was traced to factors such as a restriction from outdoor games, dressing code, traditional customs as practice in the country.

Report of data from the World Health Organisation (WHO) information about KSA more than a decade year ago specifically year 2005 showed a low percentages of high $(16 \%)$ and moderate $(16 \%)$ physical activity, and a high 
percentages of low (68\%) activity among men and women between 15-65 years old (Samara et al., 2015).

In support of this fact, other studies finding have equally established that there is a high prevalence of physical inactivity among Saudis citizen (WHO, 2005; Al-hazzaa, 2007). Early formation of habits in support of exercise in the early stages of life for sports skills development will naturally promote physical activity in schools (Black et al., 2019). Moreso, an investment in other strategies will haste the control for all levels of physical activity and related health conditions for active life course.

\section{Discussion}

This Systematic Literature Review (SLR) can be seen as the first broad review on PA/Sports activities in the Kingdom of Saudi Arabia (KSA), discussing the current state of sports activities, issues confronting the success of sports activities, and reasons for poor participation in sports activities with aim to identify gaps for further research. This is to support the KSA government and ministry of education towards sensitization of universities to encourage students and staff participation in sports activities. It also offers an alternative to economic growth for the KSA government to change the idea of total reliance on oil.

Nevertheless, our ability to investigate research trends of $\mathrm{PA} /$ Sports activities in KSA and Other Countries in the World (OCW) empirically is shown in Figures 7 and 8.
Previous studies investigation of male participant is quite low having 3 in KSA and 0 in OCW based on Table 2. This is against 7 in KSA and 0 in OCW for females. This finding negates the study of Lin and Chen (2013) which suggested that "sport is a male-dominant event that not only promotes traditional gender roles but also advances male hegemony" as acknowledged in (Hannon, Soohoo, Reel, \& Ratliffe, 2009). Therefore, it indicated that gender stereotypes may enhance or hinder sports participation among students.

The advantages of physical activity are well demonstrated for the general population (Adrianne et al., 2009; Chimen et al., 2012), and the opportunities accrue to youth and adolescents are well documented and reported (Hallal et al., 2012; Rangul et al., 2012; Tremblay et al., 2011; WHO, 2015). Sport is considered important more than the traditional education policy, for instance, a certain aspect of curriculum, class size and a vast number of students participating in high school sports suggest further research. While past research has investigated factors influencing sports participation separately, further research into the links between these factors is warranted (Lin and Chen, 2013). In addition, some studies analyse the number of participants used by gender for the conducted survey were not clearly defined with KSA (6) and OCW (9). The result revealed that researchers focused more on the use of females/males for their investigation on PA/sports-related issues as shown in Figure 7. Hence, the necessity for further research in KSA with a focus on factors influence and male involvement.



Figure 7. Empirical analysis results of selected studies by genders in KSA and OCW 


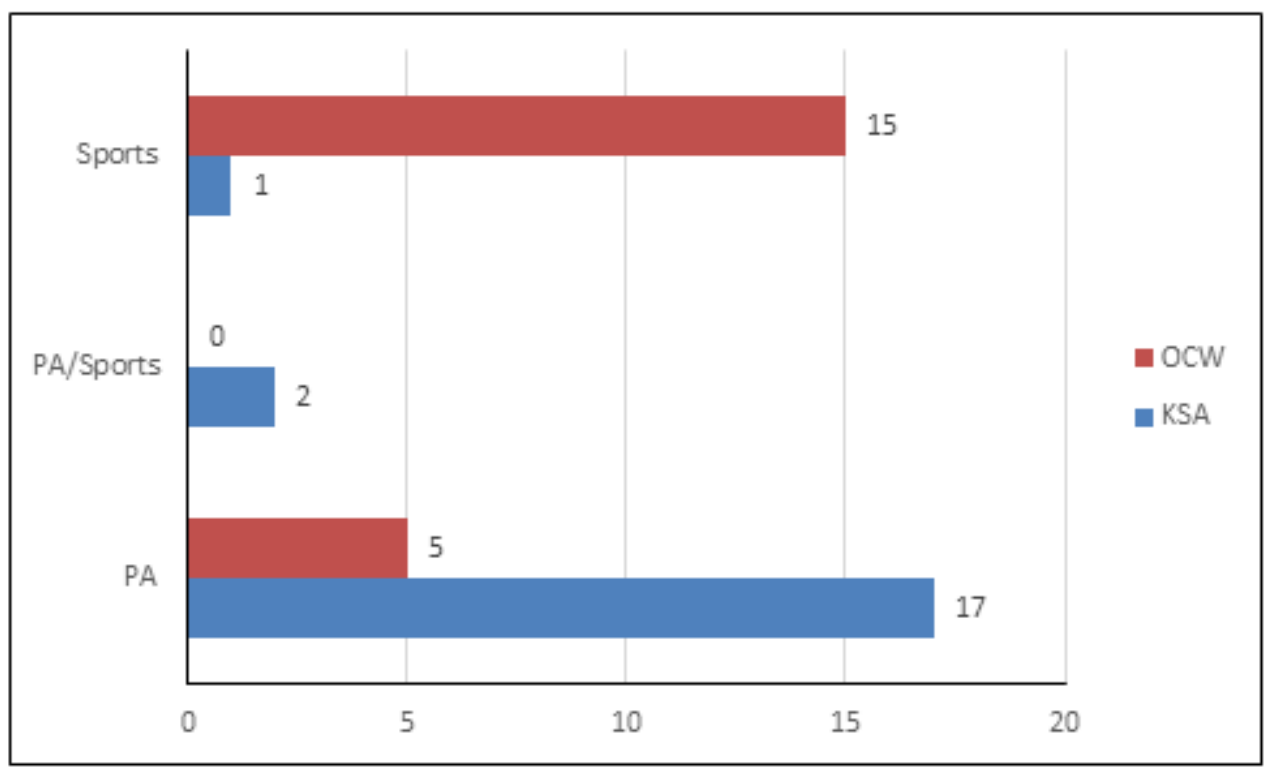

Figure 8. Empirical analysis results of selected studies on $\mathrm{PA} /$ sports research trends

In Figure 8, the empirical analyses of result from Table 3 are very low based on the researches done on sports in KSA and high in OCW. Consequently, researches conducted for $\mathrm{PA} /$ sports was drastically low in KSA and 0 from the selected studies considered for this SLR. Meanwhile, the highest result was recorded for PA related research for KSA and OCW with 17 and 5 respectively. This is against KSA policy advocating for sports activities promotion in the country (Voluntary and Review, 2018). The outcome of the findings by (Kyu et al., 2016), which concluded that a higher level of total physical activity strongly facilitated a low risk of breast cancer, colon cancer, and other chronic diseases, with most health gains happening at a total activity level of 3000-4000 MET-minutes/week. The results supported this SLR discovery at the same time suggested that participation on physical activity needs to be many times higher than the recommended minimum level of $600 \mathrm{MET}$-minutes/week for larger reductions in the risk of these diseases (Kyu et al., 2016).

Above all, involvement in physical activity and active participation in sports is encouraged. This will serve as benefits and help to reduce the risk of diseases by avoiding obesity, weight control, reduced anxiety and stress (WHO, 2015).

\section{Strength and Limitations}

This SLR study is the first to investigate the current state of PA/ sports activities in KSA and OCW. Also, the SLR serves as the first to explore and investigate the level of research on $\mathrm{PA} /$ sports facilities, factors that influence both PA and sports activities in KSA universities. This is carried out with the aim of identifying gaps to extend research that can support KSA policy on vision 2030, likewise ministry of education for the promotion of sports in the country. The SLR study is a support for the utilization of sports intervention to replace the country's dependency on oil for global economic growth by the year 2030. The study is limited in the sense that some articles might be missed out in the course of selected studies search considered. More emphasis is laid on the universities even though an in-depth study of the SLR cover other educational institutions; this is to know the extent of the following:

- what has been done in the popular literature in KSA and OCW?

- where the researches in this domain of PA and sports have reached?

- what is yet to be done and what can potentially be considered to extend the current state in KSA?

\section{Conclusion and Future Work}

Sports is an exercise needed by everyone to improve their health status. This will facilitate longer life span among citizen if practised regularly. However, it is obvious, that getting people to participate in sport to change their lifestyle with exercising habits requires a tremendous effort by those involved in community health, governmental policy, and school education. This can be encouraging if incorporated into the curriculum and resolve with authorities in different KSA universities. However, this study has presented detail SLR on the current state of PA/sports in Tables 2 and 3, likewise the analysis in Figures 7 and 8 respectively. The issues that militated against the success of PA/ sports researches are discussed in Section 4.1.3 of this article. Based on this, the research questions 1 and 2 which guided the ongoing doctoral study, reported in this article (Section 1.3) has been perfectly answered. Lesson learned is that many other countries such as United States, China, United Kingdom, Japan, South Korea and Malaysia have enjoyed global revenue benefits from sports, therefore, KSA should not be left out. Meanwhile, factors serve as a major impediment to PA /sports practices and success in KSA, likewise, lack of adequate facilities also needs serious 
attention and in-depth study on these pertinent issues will be considered in future work.

\section{REFERENCES}

[1] Ababteen, A. (2012) 'The reality of scientific publishing in Saudi universities', aljazerah, March.

[2] Action, G., On, P. and Activity, P. (2018) Global Action Plan on Physical Activity 2018-2030, More action people for healthier world. doi: 10.1016/j.jpolmod.2006.06.007.

[3] Alsolami, B., \& Embi, M. R. (2018). Crowding perception: A case study of developed systematic literature review procedure with multiple software programs as management and synthesis tools. International Journal of Engineering \& Technology, 7(2.10), 121-126.

[4] Al-hazzaa, H. M. (2004) 'the Public Health Burden of Physical Inactivity in Saudi', (January), pp. 45-51.

[5] Al-hazzaa, H. M. (2018) 'Physical inactivity in Saudi Arabia revisited: A systematic review of inactivity prevalence and perceived barriers to active living', IJHS Journal, 12(6).

[6] Al-Hazzaa, H. M. (2010) 'Physical inactivity in Saudi Arabia. An under served public health issue', Saudi medical journal, 31(11), pp. 1278-1280.

[7] Al-Anon (2018) 'World Service Conference Mission Statement'.

[8] Alahmed, Z. and Lobelo, F. (2018) 'Physical activity promotion in Saudi Arabia: A critical role for clinicians and the health care system', Journal of Epidemiology and Global Health. Ministry of Health, Saudi Arabia, 7, pp. S7-S15. doi: 10.1016/j.jegh.2017.10.005.

[9] Alghanim, S. A. and Alhamali, R. M. (2011) 'Research productivity among faculty members at medical and health schools in Saudi Arabia. Prevalence, obstacles, and associated factors.', Saudi medical journal, 32(12), pp. 1297-1303.

[10] Alsahli Maali Saud (2016) Benefits and Barriers to Physical Activity among Saudi Female University Students in the Kingdom of Saudi Arabia and the United States, Ммит. Available at: https://jewlscholar.mtsu.edu/bitstream/hand le/mtsu/5147/Alsahli_mtsu_0170N_10692.pdf?sequence $=1$ \&isAllowed $=\mathrm{y}$.

[11] Al Anizi, N. (2018) No Title University Activities Management and its role in enhancing Intellectual security. Naif Arab University for Security Sciences.

[12] Black, N. et al. (2019) 'The effect of school sports facilities on physical activity, health and socioeconomic status in adulthood', Social Science and Medicine. Elsevier Ltd, 220, pp. 120-128. doi: 10.1016/j.socscimed.2018.10.025.

[13] Castañeda-Vázquez, C. et al. (2018) 'Sport and exercise at university: How much do students really do?' doi: 10.14198/jhse.2018.13.proc2.07.

[14] Cerar, K. et al. (2017) 'Exercise Participation Motives and Engaging In Sports Activity among University of Ljubljana Students', Open Access Macedonian Journal of Medical Sciences, 5(6), p. 794. doi: 10.3889/oamjms.2017.159.

[15] Eman F. El Azab, Shereen A. Elwasefy, Hassnaa E. Shaban, F. A. M. M. A. H. A. (2019) 'Obesity Related Risk Factors
Among the Saudi Female Students in Jouf University Obesity Related Risk Factors Among the Saudi Female Students in Jouf University', 4(1), pp. 38-49.

[16] Fahad, M. G., Ali, S. and Ibrahim, R. (2016) 'A performance measurement of research productivity in Saudi Universities', Journal of Engineering and Applied Sciences, Medwell Journals, 11(3), pp. 537-544.

[17] Health Organization, W. (2018) 'Physical activity for health More active people for a healthier world: draft global action plan on physical activity 2018-2030 Report by the Director-General', 2014(December 2017), pp. 1-8. doi: 10.1016/j.jpolmod.2006.06.007.

[18] Kinninmont, J. (2017) 'Vision 2030 and Saudi Arabia's Social Contract: Austerity and Transformation', Chatam House, (July). Available at:https://www.chathamhouse.org/publicati on/vision-2030-and-saudi-arabias-social-contract-austerity-a nd-transformation\#.

[19] Kyu, H. H. et al. (2016) 'Physical activity and risk of breast cancer, colon cancer, diabetes, ischemic heart disease, and ischemic stroke events : systematic review and dose-response meta-analysis for the Global Burden of Disease Study 2013', pp. 1-10. doi: 10.1136/bmj.i3857.

[20] Maali Saud Alsahli A (2016) Benefits and Barriers to Physical Activity Among Saudi Female University Students in the Kingdom of Saudi Arabia and the United States, Mмит.

[21] McPherson, A. et al. (2018) 'Physical activity, cognition and academic performance: An analysis of mediating and confounding relationships in primary school children', $B M C$ Public Health. BMC Public Health, 18(1), pp. 1-9. doi: 10.1186/s12889-018-5863-1.

[22] McWhannell, N., Triggs, C. and Moss, S. (2017) 'Perceptions and measurement of playtime physical activity in English primary school children', European Physical Education Review, p. 1356336X1774304. doi: 10.1177/1356336X17743048.

[23] Metrics, G. H. (2018) 'Measuring progress from 1990 to 2017 and projecting attainment to 2030 of the health-related Sustainable Development Goals for 195 countries and territories : a systematic analysis for the Global Burden of Disease Study 2017', pp. 2091-2138. doi: $10.1016 / \mathrm{S} 0140-6736(18) 32281-5$.

[24] minister of higher education (2015) 'status of saudi university', higher education.

[25] MOH (2013) 'Saudi Health Interview Survey Results', pp. 6 54. Available at: http://www.healthdata.org/sites/default/files /files/Projects/KSA/Saudi-Health-Interview-Survey-Results. pdf.

[26] Organization, W. H. (2010) 'Global recommendation on PA for Health'.

[27] Parks, S. E., Housemann, R. A. and Brownson, R. C. (2003) 'Differential correlates of physical activity in urban and rural adults of various socioeconomic backgrounds in the United States', Journal of Epidemiology and Community Health, 57(1), pp. 29-35. doi: 10.1136/jech.57.1.29.

[28] Sancassiani, F., Machado, S. and Preti, A. (2018) 'Physical Activity, Exercise and Sport Programs as Effective Therapeutic Tools in Psychosocial Rehabilitation', Clinical Practice \& Epidemiology in Mental Health, 14(1), pp. 6-10. doi: $10.2174 / 1745017901814010006$.

[29] SFD (2017) 'Sport for Development and Peace Sport's role in 
national development'.

[30] Thompson, M. C. (2017) “"Saudi Vision 2030”: a Viable Response To Youth Aspirations and Concerns?', Asian Affairs. Taylor \& Francis, 48(2), pp. 205-221. doi: 10.1080/03068374.2017.1313598.

[31] Voluntary, F. and Review, N. (2018) 'First Voluntary National Review TOWARDS SAUDI ARABIA'S SUSTAINABLE TOMORROW'. Available at: https://sustainabledevelopment.un.org/content/documents/20 230SDGs_English_Report972018_FINAL.pdf.

[32] WHO (2018) 'NCDs | Physical activity', Who. Available at: http://www.who.int/ncds/prevention/physical-activity/introd uction/en/. 